\title{
Principles of capitalistic commodity production
}

\author{
Fritz Helmedag*
}

\begin{abstract}
The causal structure of capitalistic commodity production can be revealed by notionally separating total output into two categories: inecessariess bought by employees, and the rest constituting society's surplus. The rate of profit is determined in the wage good industry and becomes the system's key variable. In association with demand for, luxuries, it governs the respective amount of profit accruing to the two sectors as well as the corresponding employment. The consequences for economic policy contradict predominant recipes.

JEL classifications: AIo, BI2, EIo

Keywords: effective demand, employment, income shares, labour theory of value, rate of exploitation, rate of profit, rate of surplus value
\end{abstract}

\section{Aim and approach}

The subsequent enquiry intends to lay bare the fundamental causal relationships that determine employment and distribution in an economy based on wage labour. National income is divided into workers' remuneration and (gross) profits (including rents for natural resources as well as interest on fixed capital). The economic activity of the government and international trade are omitted. Such extensions as well as the consideration of different savings patterns (see Helmedag 2008) are still feasible without altering the results qualitatively. The derived policy implications contradict the usual recommendations and apply when productive capacities are not fully utilised so that output "can be increased in quantity by the exertion of human industry« (Ricardo I8I7: I2).

* Chemnitz University of Technology, Germany.

Correspondence Address:

Prof. Dr. Fritz Helmedag, Department of Economics, Chemnitz University of Technology, D-o9107 Chemnitz, Germany, e-mail: f.helmedag@wirtschaft.tu-chemnitz.de.

Received 20 December 20IO, accepted I2 September 2011

(C) INTERVENTION 9 (I), 20I2, 23-34 
Let us begin with a thought experiment: In our mind's eye we see the vast product variety of a modern economy - of course including services - sorted into two baskets. One contains all 'wage goods` which are purchased solely out of workers' income. The other receptacle holds the entire rest. This separation resembles Pigou's procedure in his Theory of Unemployment (1933: 7I). But this book rests on Say's law, whereas the deliberations presented here follow Keynes's (1936) line of reasoning: effective demand regulates absorbed supply. In addition, the present study is closely connected to Marx's (I867) investigation of capitalistic commodity production.

Items in the two selections do not need to be physically different, only the affiliation of buyers matters: whenever pay finances expenditures then wage goods, also called necessaries or ,basics, are acquired by definition. All other articles are declared as luxury, excess or surplus commodities. They comprise consumption goods for profit earners and investments. For the sake of simplicity, demand for these snon-basics is deemed completely autonomous, i.e. its volume appears as a given parameter.

Within this conceptual framework, let's say a paperclip or a tube of toothpaste may fit into each category. Actually, a supplier has no special interest in classifying customers as belonging to one type or the other. For businessmen it is usually without any benefit to know from which source their cash flow stems. Nevertheless, each sold object can in principle be subsumed either into necessaries or luxuries. Furthermore, in a modern economy with a sophisticated division of labour in and between firms, input-output analysis allows us to assign intermediate goods to one of the two product groups. Though, as we shall see, no empirical survey has to be conducted in order to disentangle the proceeds. It suffices to interpret national accounting figures appropriately.

The demand-oriented dichotomy proposed here is similar to the hierarchical scorn models propagated by doyens of classical political economy (see Skourtos 199I): the basic sector produces a wage good - e.g. wheat - used as input - e.g. seeds and food - to create the surplus in its concrete form in the non-basic branch which is not viable on its own. This supply-side distinction has been designed to unveil the causal structure of commerce and industry. ${ }^{\mathrm{I}}$

Nowadays, in contrast, an roverall economic interdependences is widely taken for granted. This attitude mirrors the dominance of the 'General Equilibrium Theory` in economics. ${ }^{2}$ Such a line of thought, however, suffers from circular explanations. Thus, without identifying the driving forces beneath the surface, the modus operandi of modern capitalism remains shrouded in mystery. Consequently, in public as well as academic discourses, incompatible propositions reflecting disparate views are exchanged. Yet, scientific progress requires a glance behind the facade of merely surmised or supposed interrelations allegedly operating on an equal footing. The dissection of revenues into sales bound for wage earners

I David Ricardo pioneered the idea in his famous ıessay on profits (I8I5). But in reality a worker neither lives from wheat alone nor is output strictly destined only for a certain class of society.

2 Upon closer inspection the ruling doctrine proves itself far less general than many disciples seem to think, see Helmedag (1999). 
on the one hand, and the remainder on the other hand renders visible what otherwise stays unrecognised behind the scenes.

\section{Basis and superstructure}

The level of employment hinges on the volume of output and the labour expended to manufacture its components. Therefore, a sketch how to calculate the labour embodied in both categories of final demand appears appropriate.

By assumption, the input-output coefficients are given. Moreover, from the macroeconomic perspective all intermediate goods as well as the physical depreciation of the (real) capital stock are (re)produced concurrently. In contrast to a ssuccessive approach where each output element is in the same completion phase we suppose a simultaneous production with an evenly staggered maturity structure. Consequently, in every instant of time the making of some commodities is finished while that of others has just begun, i.e. the fabrication process is perfectly synchronised. Finally, we operate with an average labour productivity so that differences in equipment and skills on the individual level are balanced out. The total amount of this homogenous labour time $v_{j}$ that is materialised in an output item results from the following set of equations:

$$
v_{j}=\sum_{i=1}^{n} a_{i j} v_{i}+a_{0 j} \quad i, j=1,2, \ldots, n
$$

The coefficients $a_{i j}$ indicate the immediate quantity of a good $i$ necessary to produce one unit of commodity $j\left[q_{j}\right]^{3}$. Accordingly, direct labour requirements - measured e.g. in hours are symbolised by $a_{0 j}\left[h / q_{j}\right]$. In matrix notation, the working time bestowed on basic goods $\left(L_{B}\right)$ produced during a reference period $[T]$ - for example a week - adds up to:

$$
L_{B}=\mathbf{v y}_{B}=\mathbf{a}_{0}(\mathbf{I}-\mathbf{A})^{-1} \mathbf{y}_{B}
$$

The $n$-dimensional row vector $\mathbf{v}$ represents the labour values which result from the solution of system (1). The column vector $\mathbf{y}_{B}$ lists the aggregate of the respective commodity acquired with wage incomes. If workers do not buy an object at all, a zero is inserted at the corresponding place. Since workers do not live on air, at least one element in the vector $\mathbf{y}_{B}$ is positive. I stands for the identity matrix, A denotes the square matrix of the coefficients $a_{i j}$, and the row vector $\mathbf{a}_{0}$ encompasses direct labour inputs. Equation (2) refers to the vertically integrated ' wage good sector which is embedded in the economy. ${ }^{4}$

Analogously, the activity level in the luxury branch $\left(L_{X}\right)$ is given by:

$$
L_{X}=\mathbf{v y}_{X}=\mathbf{a}_{0}(\mathbf{I}-\mathbf{A})^{-1} \mathbf{y}_{X}
$$

4 For the fruitfulness of the approach see Pasinetti (I993). 
The column vector $\mathbf{y}_{X}$ records all items of final demand which are not financed from paid employment. Obviously, the problem of numerically calculating $L_{B}$ and $L_{X}$ consists in collecting adequate data to specify the vectors $\mathbf{y}_{B}$ and $\mathbf{y}_{X}$. Fortunately, relevant economic policy recommendations can be inferred without having to determine the labour volumes $L_{B}$ and $L_{X}$ incorporated in sales to the corresponding class of costumers.

Next we declare an arbitrary and fictitious unit as the idiosyncratic output of the sector under consideration. For instance, say $X(10,100,1000, \ldots)$ 'pieces of surplus goods carrying the (synthetic) dimension $\left[q_{X}\right]$ are produced within seven days. Each item embodies a labour value $v_{X}$, which, of course, depends on the above defined number of excess articles $X$. That device allows us to create an exemplary luxury resp. wage good, both unrelated to specific use values in reality. Due to this virtual division of the economy in the two subsystems its inner structure will become clearer. In addition, easily accessible statistical information will make a quantitative illustration possible.

Dividing the number of working hours in the stylised industry $L_{X}$ by the supposed output $X$ yields the vertical integrated labour time realised in one unit of the imaginary surplus good:

$$
v_{X}=\frac{L_{X}}{X} \quad\left[\frac{h}{q_{X}}\right]
$$

The quantity of the representative wage commodity per reference period $(B)$ is also fixed at will. The corresponding labour value $v_{B}$ reads:

$$
v_{B}=\frac{L_{B}}{B} \quad\left[\frac{h}{q_{B}}\right]
$$

The surplus artefact is priced at $p_{X}\left[M / q_{X}\right]$ expressed in (accounting) money $[M]$ per component $\left[q_{X}\right]$, whereas the consumption element for the workers would cost $p_{B}\left[M / q_{B}\right]$. Multiplying the uniform real compensation pro rata temporis $(w)$ in units of the synthetic basic good $\left[q_{B} / h\right]$ with its imputed price gives the nominal wage rate $w p_{B}[M / h]$.

\section{A percentage that counts}

The entire outlay in each concocted sector comprises the expenditure on labour at every stage of production. Since input and output values are dimensionally homogenous in the branch creating necessaries, the department's rate of profit is reducible to a pure number:

$$
s=\frac{B p_{B}-B v_{B} w p_{B}}{B v_{B} w p_{B}}=\frac{1-v_{B} w}{v_{B} w}
$$

For a given labour value of the basic good $v_{B}$, the real wage $w$ and the rate of profit $s$ move in opposite directions. But the latter variable is not only a `monetary` relation between 
profit and costs. What is more, the fraction can be given a Marxian interpretation in two characteristic varieties. On the one hand, $s$ represents a material rate of surplus value. A further division of equation (6a) by $v_{B}$ leads to:

$$
s=\frac{\frac{1}{v_{B}}-w}{w}
$$

The reciprocal of the labour value $1 / v_{B}$ indicates the output of one hour of standard working time and corresponds to the average productivity in the basic sector. Therefore, equation (6b) also expresses the 'physical ratio of the surplus to the real remuneration $w$, with both measured in units of the (artificial) wage good. On the other hand, a stemporal elucidation of equation (6a) is possible. Dividing numerator and denominator by $w$ results in:

$$
s=\frac{\frac{1}{w}-v_{B}}{v_{B}}
$$

The quotient $1 / w$ informs about the worth of one wage good in terms of labour time. Adam Smith called this amount slabour commanded in contrast to the slabour embodied in a basic commodity $v_{B}$. So to speak, the difference between the two quantities refers to the time in which the employee expends his powers for his employer. The numerator of the rate of exploitation (6c) reflects this surplus labour . In the present analytical framework, the three outlined interpretations of profitability coincide.

Yet, many economists believe that the rate of profit has to be applied to a capital stock inherited from the past. ${ }^{5}$ Then, in order to get profit as a flow magnitude, the rate of profit turns more or less secretly from a pure mark-up factor into something like a rate of interest related to a time interval in the denominator (mostly a year). But this interpretation mixes up the objective of an investor (maximising a fund's yield) with that of an entrepreneur (making the difference between proceeds and spending as large as possible).

Obviously, the rates $(6 \mathrm{a}-\mathrm{c})$ only depend on the amount of the real wage $w$ and the productivity in its creation $1 / v_{B}$. Both variables are determined solely in the production of necessaries. Thus, classical economists labelled the basic sector sproductive for the reason that it generates the surplus needed to feed the labour force in the luxury division (see Smith I776: 330-33I). In this part of the economy workers give shape and form to the excess goods consumed by others. Despite being disparaged as sterile, activities in this branch are also lucrative and welfare-enhancing because profits emerge and wants are met.

5 Marx' rate of profit also includes a symbol for 'constant capital. Actually, a perfectly synchronised production process continuously reproduces all factors used up in each phase of operation. Therefore, no recourse to an output stemming from prior production is needed. Hence Marx has been a victim of a successive instead of a simultaneous reasoning, too. This misconception entailed the famous stransformation problem`. For more details see Helmedag (1994: 172-186). 
The numerator in the centre of equation (6a) portrays the profit of the fictitious basic segment. Net gain is obtained after expenditures for natural resources (and possibly the debt service on outside capital) are deducted. Individually, profit maximising protagonists always strive for higher revenues and lower costs. Therefore, business executives encounter both incessant incentives as well as persistent pressures, particularly to reduce the wage bill in a system of capitalistic commodity production. Investments in machinery increase labour productivity and give rise to rents in the same way as do different qualities of natural resources. In the end, the efforts to curtail expenses are reflected in a falling socially necessary labour time`; process innovations regularly increase output per capita.

Although a low compensation seems favourable from the viewpoint of a single entrepreneur, this does not apply for employers as a whole: a higher remuneration of staff offers business opportunities for the wage good industry. This fact constitutes one of the driving contradictions of capitalism: no mass market demand without mass purchasing power!

The existence of profit implies that the productivity in the basic sector exceeds the real wage:

$$
s>0 \text { for } \frac{1}{v_{B}}>w
$$

As a system's characteristic, condition (7) must be fulfilled. At the aggregate level, this causes a positive profit share in national income. According to the prevalent view, a person's unemployment ensues from a pay claim which is deemed too high compared to the individual's performance. Yet, this opinion does not stand up to closer examination.

\section{From price formation to employment determination}

In contrast to the wage good industry, the surplus department is unable to independently establish its profit rate $\left(s_{X}\right)$ :

$$
s_{X}=\frac{X p_{X}-X v_{X} w p_{B}}{X v_{X} w p_{B}}=\frac{p-v_{X} w}{v_{X} w} \text { with } p=\frac{p_{X}}{p_{B}}
$$

Under perfect competition, hypothetical arbitrage occasions emerging from sales to workers or other consumers are excluded. In equilibrium the luxury division calculates with the same profit rate as the basic sector. Equating formulae (6a) and (8) leads to the relative price in our two-commodity world:

$$
p=\frac{v_{X} w\left(1-v_{B} w\right)+v_{X} v_{B} w^{2}}{v_{B} w}=\frac{v_{X}}{v_{B}}=\frac{p_{X}}{p_{B}} \quad\left[\frac{q_{B}}{q_{X}}\right]
$$


A uniform rate of profit in the dichotomised economy vindicates the llaw of values: the labour embodied in the two categories of objects governs the equivalence ratio. ${ }^{6}$ In this pure stechnical formation of a sprice of production $`$ neither the level of compensation nor a market mechanism resorting to supply and demand plays a role.

In our laboratory, profits accruing to the wage good sector $\left(\Pi_{B}\right)$ are equal to total labour costs in the luxury segment: $\Pi_{B}=L_{X} w p_{B}=X_{B} p p_{B}[M / T]$, where $X_{B}$ denotes the quantity of surplus output attributed to the basic industry. With recourse to equations (4) and (9) we get: $X_{B}=X v_{B} w<X$. Hence, the non-basic branch absorbs $X_{X}=X\left(1-v_{B} w\right)>0$. It becomes obvious again that individually motivated efforts to reduce payment eventually run counter to the interests of the fictitious basic good manufacturers as a whole. In proportion to the revenues originating from wages, firms are caught in a rationality trap. However, entrepreneurs in this sphere are usually unaware of their prisoner's dilemma situation because they simply do not know from which sources their proceeds stem.

Employment in the production of necessaries $\left(L_{B}\right)$ is influenced by the rate of profit which simultaneously determines the relation of labour inputs:

$$
L_{B}=\frac{L_{X} v_{B} w}{1-v_{B} w}=\frac{L_{X}}{s}=\frac{v_{X} X}{s}
$$

Apparently, the rate of profit and the number of employees in the wage good industry are negatively correlated. The entire working time performed in the period under consideration $(L)$ amounts to:

$$
L=L_{X}+L_{B}=v_{X} X\left(1+\frac{1}{s}\right)=\frac{L_{X}}{1-v_{B} w} \quad\left[\frac{h}{T}\right]
$$

Productivity gains lessen the need for manpower, whereas a higher demand for luxuries and a rising real wage - up to the limit stated in condition (7) - entail additional labour requirements. Particularly this insight reverses the mainstream's doctrine. In capitalism, paid employment ultimately serves as a means to an end: the creation of the hierarchically higher ranking surplus commodities. Notwithstanding, worker's living conditions may change for the better as long as unexhausted production possibilities exist. When technology, working hours and the volume of luxuries are given, then a greater wage basket always generates more jobs. Thus, in the final analysis, a rising material compensation is tantamount to a Paretoimprovement: employees enjoy additional consumption without impairing the welfare of the capitalist class.

6 This is also true if profits are not related to vertically integrated labour costs but to sectoral revenues in equations (6a) and (8). Equilibrium in this case is characterised by the same percentage return on sales. Further, the labour theory of value is empirically well supported, see Fröhlich (2009). 


\section{Profit's source, size and sharing}

Augmented total costs in the vertically integrated branches constitute the money value of their output. Therefore, the mark-up established in the basic sector $(1+s)$ can be interpreted as an indicator of the production price level. It tallies with the proportion of productivity $\left(1 / v_{B}\right)$ to the real remuneration $(w)$. The latter quantity affects the wage bill $(W)$, too:

$$
W=L w p_{B}=\frac{L_{X} w p_{B}}{1-v_{B} w} \quad \text { with } \quad \frac{\partial W}{\partial w}=\frac{L_{X} p_{B}}{\left(1-v_{B} w\right)^{2}}>0
$$

Exploitation means that the workers' payment does not suffice to buy nominal net output, i.e. the rate of profit is positive. Then, the share of wages in national income $(z)$ falls below Ioo per cent and corresponds to real unit labour costs $\left(v_{B} w p_{B} / p_{B}=v_{B} w\right)$ :

$$
z=\frac{L w p_{B}}{L w p_{B}(1+s)}=\frac{1}{1+s}=v_{B} w<1
$$

Substituting the equivalence ratio (9) into the middle numerator of equation (8) yields the profits $\left(\Pi_{X}\right)$ accruing to non-basic firms:

$$
\Pi_{X}=X p_{X}-X v_{X} w p_{B}=v_{X} X p_{B}\left(\frac{1}{v_{B}}-w\right)=L_{X} p_{B}\left(\frac{1-v_{B} w}{v_{B}}\right)
$$

As a result, the rate of profit becomes the system's key variable since it informs about the allocation of the labour force, the allotment of the surplus and the appropriation of profits:

$$
s=\frac{L_{X}}{L_{B}}=\frac{X\left(1-v_{B} w\right)}{X v_{B} w}=\frac{X_{X}}{X_{B}}=\frac{L_{X} p_{B}\left(\frac{1-v_{B} w}{v_{B}}\right)}{L_{X} p_{B} w}=\frac{\Pi_{X}}{\Pi_{B}}
$$

With a given demand for excess commodities and a constant productivity in the fabrication of necessaries, a changing real wage $w$ entails redistribution between the sectors: a rising rate of profit increases the part of the surplus earmarked for the luxury division, whereas the share of the basic department decreases et vice versa. At a profit rate of Ioo per cent $(s=1)$, gains in both industries are equal. From this point of view, a conflict of interests exists between enterprises operating in the two separated spheres.

The sum of profits $(\Pi)$ amounts to:

$$
\begin{aligned}
\Pi & =\Pi_{B}+\Pi_{X}=L_{X} p_{B}\left(w+\frac{1-v_{B} w}{v_{B}}\right) \\
& =\frac{L_{X} p_{B}}{v_{B}}=\frac{v_{X} X p_{B}}{v_{B}}=X p p_{B}=X p_{X} \quad\left[\frac{M}{T}\right]
\end{aligned}
$$


Evidently, nominal profits $\Pi$ coincide exactly with the disbursement for non-basic goods $X p_{X}$. Entrepreneurs will earn later whatever they had spent beforehand for consumption and investments. This complete conversion of employers' expenditures into their own income takes place regardless how much the workers receive for labour services. ${ }^{7}$ By the same token, the rate of profit has no impact on aggregate gains but shapes the economy's inner structure as described by expression (15).

\section{Causalities in capitalism}

Equations (6a-c), (10) and (11) provide some insights concerning economic policy. The following statements are valid ceteris paribus:

- Working longer without appropriate real wage adjustments raises the rate of profit and hence causes dismissals,

- a falling production of luxuries diminishes employment not only in this branch but in the basic sector too,

- labour productivity growth in the wage good industry accompanied by an underproportional increase in pay leads to lay-offs,

- $\quad$ even if productivity improvements in the basic sector are matched exactly by higher real wages, the workforce shrinks whenever output per capita in the luxury division also expands.

At any rate, the very compensation of redundancies resulting from process innovations let alone promoting employment as such - requires a mixture of shorter hours, enhanced earnings or a greater demand for luxuries. ${ }^{8}$ Of course, more and better public services may be an integral part of the programme. All in all, these suggestions fit well with the Keynesian message.

Furthermore, labour demand will decline when workers receive a waning share in national income. This is accompanied by a rising rate of profit. As an antidote, higher instead of lower wages appear opportune. This gives workers more purchasing power provided that their pay rises faster than prices. Then additional job opportunities emerge. ${ }^{9}$

With gross domestic product (GDP), the number of working hours and labour costs it is possible to empirically illustrate the preceding analysis. Table I presents the functional

7 Kalecki deserves credit for this finding which is sometimes associated with a 'paradox of costs . For details see Hein (2008).

8 The latter aspect has been emphasised already by Mandeville (I723).

9 Actually, from a theoretical and an empirical perspective, doubts arise whether a central bank can fight inflation by means of higher interest rates. There are indications that the reverse direction of cause and effect applies, see Helmedag (2009a) and (2009b). 
distribution of income in selected industrialised countries. As it were, this compilation highlights the global balance of power between labour and capital.

Row (6) reflects the level of production prices corresponding to the mark-up $(1+s)$. This factor coincides with the reciprocal of the real unit labour costs in the basic sector $\left(1 / v_{B} w\right)$ or, as mentioned above, the relation of productivity to the real wage. According to the evidence, employees in Germany are worse off than their colleagues in other nations because they can repurchase less of the relatively expensive output with their pay. ${ }^{10}$

Table I: An international comparison (2010)

\begin{tabular}{|c|c|c|c|c|c|}
\hline Countries & Germany & Japan & France* & Great Britain & USA \\
\hline $\begin{array}{c}(1) \\
\text { GDP in } \\
\text { millions }\end{array}$ & $\begin{array}{c}2,476,800 \\
\text { EUR }\end{array}$ & $\begin{array}{c}479,179,200 \\
\text { JPY }\end{array}$ & $\begin{array}{c}1,907,145 \\
\text { EUR }\end{array}$ & $\begin{array}{c}1,463,734 \\
\text { GBP }\end{array}$ & $\begin{array}{c}14,447,100 \\
\text { USD }\end{array}$ \\
\hline $\begin{array}{l}(2) \\
\text { Total hours } \\
\text { worked by } \\
\text { employees } \\
\text { in thousands }\end{array}$ & $48,346,749$ & $95,107,040$ & $36,797,166$ & $40,811,013$ & $229,834,948$ \\
\hline $\begin{array}{l}\text { (3) } \\
\text { Labour costs** } \\
\text { per hour }\end{array}$ & $\begin{array}{c}26.09 \\
\text { EUR }\end{array}$ & $\begin{array}{c}2,650 \\
\text { JPY }\end{array}$ & $\begin{array}{c}27.32 \\
\text { EUR }\end{array}$ & $\begin{array}{c}19.65 \\
\text { GBP }\end{array}$ & $\begin{array}{c}34.72 \\
\text { USD }\end{array}$ \\
\hline $\begin{array}{c}(4) \\
\text { Labour } \\
\text { productivity } \\
\text { (GDP per hour) } \\
(1) /(2)\end{array}$ & $\begin{array}{c}51.23 \\
\text { EUR }\end{array}$ & $\begin{array}{c}5,038 \\
\text { JPY }\end{array}$ & $\begin{array}{c}51.83 \\
\text { EUR }\end{array}$ & $\begin{array}{c}35.87 \\
\text { GBP }\end{array}$ & $\begin{array}{c}62.86 \\
\text { USD }\end{array}$ \\
\hline $\begin{array}{c}(5) \\
\text { Real unit } \\
\text { labour costs } \\
(3) /(4)\end{array}$ & 0.51 & 0.53 & 0.53 & 0.55 & 0.55 \\
\hline $\begin{array}{c}(6) \\
\text { Production } \\
\text { price level } \\
1 /(5)\end{array}$ & 1.96 & 1.90 & 1.89 & 1.82 & 1.81 \\
\hline
\end{tabular}

${ }^{*}$ Data refer to 2009; ${ }^{* *}$ Compensation including employers' contributions to social security.

Source: OECD, stats.oecd.org [5th March 2012]

However, and quite contrary to popular opinion, interests of entrepreneurs with respect to the wage issue diverge. Indeed, a rise in remuneration stimulates the production financed out of workers' income and thus more profits accrue to this sphere. The opposite holds for the

IO As a matter of fairness, the rate of profit should be 6I.8 per cent, see Helmedag (20I0). This percentage falls short of the figures in the last line minus I (respectively roo per cent). 
surplus department. Remarkably, in case of idle capacities, higher wages do not bring down total profits. Rather, as equation (16) shows, dwindling nominal gains are caused either by a relatively low growth of productivity in the basic sector compared to the development in the luxury industry or by a reduced demand for excess commodities. This outcome corroborates an insight of the circular flow theory, viz. that expenditures of capitalists keep returning to them again. Alas, common knowledge in this respect is also a scarce good.

\section{References}

Fröhlich, N. (2009): Die Aktualität der Arbeitswerttheorie: Theoretische und empirische Aspekte, Marburg: Metropolis.

Hein, E. (2008): Money, Distribution Conflict and Capital Accumulation: Contributions to ,Monetary Analysis‘, Basingstoke: Palgrave Macmillan.

Helmedag, F. (1994): Warenproduktion mittels Arbeit, Zur Rehabilitation des Wertgesetzes, $2^{\text {nd }}$ ed., Marburg: Metropolis.

Helmedag, F. (1999): Ohne Werte und kreislaufschwach: Zum Status der Allgemeinen Gleichgewichtstheorie, in: Helmedag, F., Reuter, N. (eds.), Der Wohlstand der Personen, Festschrift zum 60. Geburtstag von Karl Georg Zinn, Marburg: Metropolis, 43-68.

Helmedag, F. (2008): Income effects of investments and wages when saving rates differ, in: The Manchester School 76, 708-719.

Helmedag, F. (2009a): Getrennt marschieren, vereint schlagen: Nationale Geldpolitik im EuroRaum, in: Ohr, R. (ed.), Internationalisierung der Wirtschaftspolitik, Berlin: Duncker \& Humblot, 39-5I.

Helmedag, F. (2009b): Europäische Geldpolitik in der Krise, in: Chaloupek, G., Kromphardt, J. (eds.), Finanzkrise und Divergenzen in der Wirtschaftsentwicklung als Herausforderungen für die Europäische Währungsunion, Marburg: Metropolis, I08-I2I.

Helmedag, F. (20I0): Fair wages and social welfare, in: Journal of Income Distribution, 19, 3-8.

Keynes, J.M. (1936): The General Theory of Employment, Interest and Money, in: The Collected Writings of John Maynard Keynes, Vol. VII, London: Macmillan, 1978.

Mandeville, B. (1723): Die Bienenfabel oder private Laster als gesellschaftliche Vorteile, München: C.H. Beck, I988.

Marx, K. (1867): Das Kapital, Erster Band: Der Produktionsprozeß des Kapitals, in: Marx-EngelsWerke, Bd. 23, Berlin: Dietz Verlag, 1977.

Pasinetti, L.L. (1993): Structural Economic Dynamics - A Theory of the Economic Consequences of Human Learning, Cambridge: Cambridge University Press.

Pigou, A.C. (1933): The Theory of Unemployment, London: Frank Cass \& Co. Ltd., I968.

Ricardo, D. (I815): An Essay on the Influence of a low Price of Corn on the Profits of Stock, in: Sraffa, P. (ed.), The works and correspondence of David Ricardo, Vol. IV, Cambridge: Cambridge University Press, 195I, 9-4I.

Ricardo, D. (I8I7): On the Principles of Political Economy and Taxation, in: Sraffa, P. (ed.), The works and correspondence of David Ricardo, Vol. I, Cambridge: Cambridge University Press, I970. 
Skourtos, M. (199I): Corn models in the classical tradition: P. Sraffa considered historically, in: Cambridge Journal of Economics $15,215-228$.

Smith, A. (1776): An Inquiry Into the Nature and Causes of the Wealth of Nations, Vol. I, Oxford: Oxford University Press, I979. 